\title{
Participatory Irrigation Management and its Financial Viability: A Case Study
}

\author{
WAQAR A. JEHANGIR, M. MUdASSER, and ZAKIR HuSSAIN
}

\section{INTRODUCTION}

Water is a key input of agriculture. In the past, the area under cultivation was small and there was less stress on farmers to grow more and more of each crop. Water was considered a free good. The situation has changed since. The increase in cropping intensity has led to a rise in the demand for irrigation water. Water is not a free good any more. The provision of irrigation water to the farmer's fields is going to be costlier.

The Government of Pakistan is spending heavily on the operation and maintenance of the irrigation system yet shortage of funds is a major reason for deferred maintenance, which threatens the operational integrity of the irrigation system [World Bank (1988) and Haq (1995)]. The shortfall in O\&M funding was estimated to be more than 24 percent in 1993 [World Bank (1994)]. As poor O\&M has direct effect on the productivity of agriculture, indirectly it affects the whole economy [Carruthers (1981)]. The allocation of funds for the increasing O\&M costs is becoming a problem for the Government of Pakistan with every successive year. One logical answer to this problem is to increase abiana ${ }^{1}$ fees from the users of irrigation water supplies. The revenue collected through abiana may be used for O\&M purposes, but it has been reported that the revenue collection is far less than the expenditures incurred. Resultantly the gap has been increasing every year [Chaudhry (1989)].

This situation demands investigation of abiana recovery and increasing O\&M costs to know the real situation which in turn will help in deciding whether it is feasible to divert the financing of O\&M activities towards farmer organisations (completely or partially). This paper aims at estimating the present level of operation and maintenance expenditures of the H-4-R Distributary and the present situation of the abiana collection and the extent of its leakage through different means.

Waqar A. Jehangir and M. Mudasser are Senior Agricultural Economist and Agricultural Economist in International Irrigation Management Institute (IIMI), Lahore and Zakir Hussain is Cotton Commissioner in Ministry of Food, Agriculture and Livestock, Islamabad, respectively.

${ }^{1}$ In Pakistan, abiana is an area-based fee differentiated by crop and is widely regarded as a user charge for canal irrigation water provided by the Provincial Irrigation Department [Small (1994)]. 


\section{Objectives}

The specific objectives of the study are:

- estimate O\&M expenditures incurred on Hakra 4-R Distributary;

- determine the abiana collection from Hakra 4-R Distributary;

- study the gap between O\&M expenditures on the irrigation system and receipts from abiana on H-4-R Distributary;

- find out the under-assessment of abiana, estimated through the survey data and through registers of irrigation revenue assessment department; and

- report farmers' perception of the problem and provide future guidelines for abiana collection on Hakra 4-R Distributary.

\section{The Physiography of the Study Area}

The provision of water in the H-4-R Distributary depends upon a number of upstream irrigation Link Canals and Barrages as shown in Figure 1. Eastern Sadiqia Canal originates from the left bank of the Sulemanki Headworks. After covering a distance of about 46 miles (74 kilometers) it splits into Hakra Branch Canal, Malik Branch Canal and Sirajwah Distributary. Three distributaries, Hakra 1-L Distributary, Hakra 3-R Distributary, and Hakra 4-R Distributary originate from the main Hakra Canal near Head Gulab Ali, while main Hakra Canal continues its journey towards the tail reaches. The gross area and the canal command area of the Eastern Sadiqia

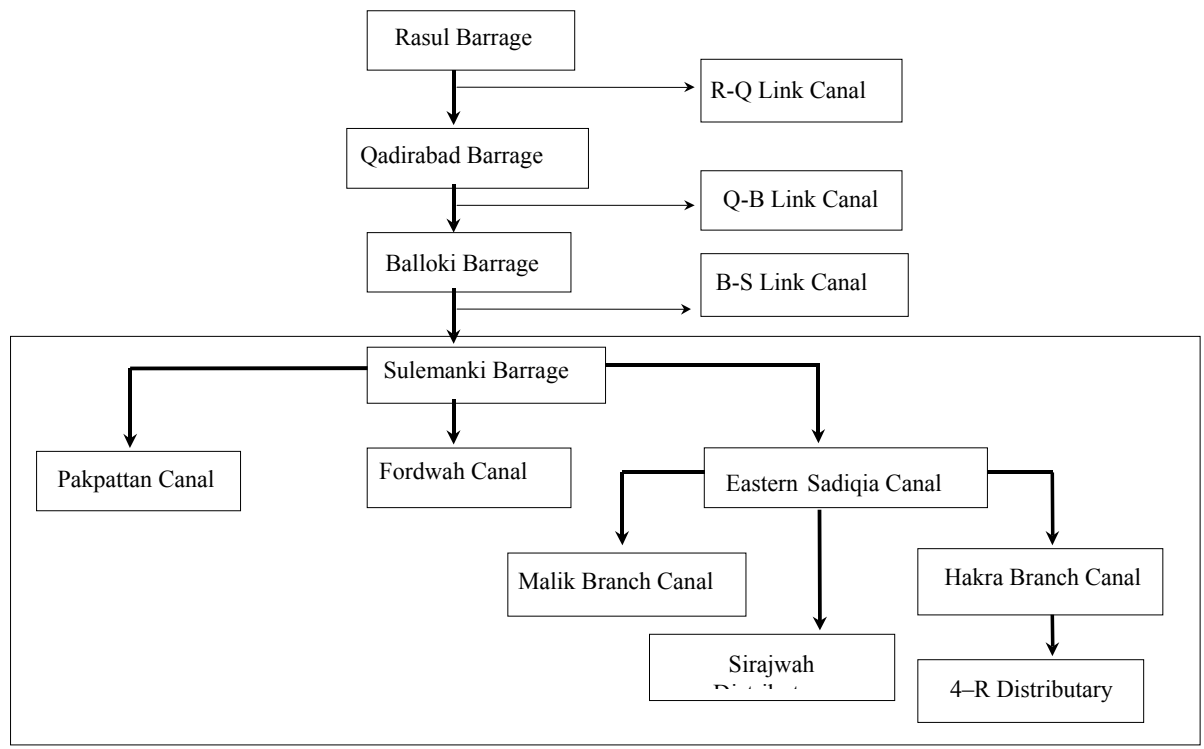


Fig. 1. System Outlay of Hakra 4-R Distributary.

Canal is about 298,000 acres and 259,000 acres, respectively. Out of this, the Hakra 4-R Distributary covers a gross command area and a canal command area of about 50,000 acres and 44,000 acres, respectively. The main H-4-R Distributary is about 112,000 feet $\left(34.14 \mathrm{~km}\right.$.) ${ }^{2}$ long with two minors; 1R and 1RA (which are $6.70 \mathrm{~km}$. and $15.43 \mathrm{~km}$. in length, respectively). The H-4-R Distributary has 123 outlets. $^{3}$ The design discharge of the H-4-R Distributary is 193 cusecs.

\section{METHODOLOGY}

The main distributary was stratified into head, middle, and tail reaches. The minor 1-R was accounted in the head reach as it emerges from there. Thirteen watercourses were selected randomly from these three reaches (proportionate to the number of total watercourses in the respective reaches). On each watercourse nine respondents were randomly selected and finally a stratified random sampling technique was used to draw out a sample of 117 farmers.

\section{Data Collection}

The primary data were collected from the farmers on a well-designed pretested questionnaire and from PID officials and contractors on a semi-structured questionnaire. The secondary data (regarding O\&M expenditures and abiana collected from H-4-R Distributary) during kharif 1995 and rabi 1995-96 were collected from PID office Bahawalnagar, Tehsildar ${ }^{4}$ office at Bahawalnagar, SDO's office at Haroonabad, and Tehsildar's office at Haroonabad.

\section{Limitations of the Study}

The study is subject to following limitations.

(1) The operational expenditures comprised the salary of the staff and the POL expenditures only. The data about expenditures on utilities were not available.

(2) The data about the operational expenditures did not include the depreciation cost of buildings being used by PID.

(3) The farmers who irrigate land by purchasing the water from tubewells also reported paying the abiana. These tubewells expenses were not taken into consideration in the study. The expenditures incurred on the SCARP ${ }^{5}$ tubewells were not included in the O\&M costs.

\section{RESULTS AND DISCUSSION}

In general, the increasing gap between O\&M expenditures and abiana collection is reported to have widened with each passing year. The decrease in abiana

${ }^{2} 1$ foot $0.3048 \mathrm{~m}$; Length of Distributary $=112000 \times 0.3048 / 1000=34.14 \mathrm{~km}$.

${ }^{3}$ Source: Irrigation Department, Bahawalnagar (1996).

${ }^{4} \mathrm{~A}$ person who is incharge of abiana collection at district level.

${ }^{5}$ Salinity Control and Reclamation Project. 
collection may occur due to three reasons. (i) Exemption from abiana payment due to the failure of crops (some natural calamity in that area). (ii) ID levied abiana but the farmers were not able to pay due to poor harvest, etc. (iii) Under-assessment of abiana (i.e., by offering gifts to Patwari who makes the inventory of the crops and assesses the abiana accordingly).

Firstly, no evidence was found that the farmers were exempt from the abiana payment. Out of 117 sample farmers, only a single farmer reported crop failure both in kharif 1995 and rabi 1995-96, and the abiana levied on him was decreased accordingly.

Secondly, none of the farmers is entitled to refrain from abiana payment for any reason. If farmers face a genuine problem, like the failure of crops due to some natural calamity, they have to report the incident to the relevant irrigation official. Then actions would have been taken to assess the whole situation. In this procedure the Patwari ${ }^{6}$ plays a vital role. If the Patwari happens to be in the farmer's favour, then the chances exist that the affected farmer will be exempt from abiana payment. On the other hand, if the farmers do not report any calamity and do not pay the abiana, then the Tehsildar may enforce the judiciary powers to collect the abiana. Table 2 shows that during the kharif 1995 and rabi 1995-96, there was not even a single farmer who refused abiana payment.

Finally, the only valid reason by which abiana payments may be reduced for the farmers is "under-assessment". But this process is not simple. The entries in $\mathrm{Khasra}^{7}$ are filled by the Patwaries and they do not honour anybody's claim unless provided with some "gifts" ${ }^{\prime}$ as unauthorised payments. The Patwari is usually reported to demand a part of total abiana, etc. for under-assessment.

Table 1 shows that about 59 percent of the respondents never paid any unauthorised payment. The rest 41 percent respondents reported unauthorised payment to the Patwari for under-assessment of abiana. Chaudhry (1986) has also reported a similar finding.

Table 2 shows the comparison of abiana estimated from the actual records (IIMI Survey 1996 data) and the abiana assessed by PID (in Khatoonies). It indicates that farmers' at the middle reach of the distributary should have paid Rs 44,660 but abiana actually assessed by PID was Rs 34,330, showing an under-assessment of about 23 percent. Likewise, the farmers at middle and tail reaches indicated an under-assessment of 20 percent and 15 percent, respectively. Clearly, farmers' at all three portions of the distributary are involved in activities leading to the underassessment of the abiana, but the major beneficiaries are the farmers located at the middle reaches of the distributary. The overall abiana under-assessment during the year 1995-96 was reported to be about 20 percent.

${ }^{6} \mathrm{~A}$ lower cadre ID official who is responsible for entering records of crops grown by a farmer in the specific registers.

${ }^{7}$ Register in which the records of all crops grown by a farmer are kept.

${ }^{8} \mathrm{Gifts}$ in the form of cash/kind. 
Table 1

Distribution of the Sample Farms According to Money Demanded by the Patwari and Their Location along Hakra 4-R Distributary

\begin{tabular}{|c|c|c|c|c|c|c|c|c|}
\hline \multirow{4}{*}{$\begin{array}{l}\text { Location along } \\
\text { Distributary }\end{array}$} & \multirow{3}{*}{\multicolumn{2}{|c|}{$\begin{array}{c}\text { Farms } \\
\text { Reporting no } \\
\text { Cash or Kind } \\
\text { Payment }\end{array}$}} & \multirow{2}{*}{\multicolumn{4}{|c|}{ Farms Reporting Cash Payment }} & \multirow{3}{*}{\multicolumn{2}{|c|}{$\begin{array}{l}\text { Farms } \\
\text { Reporting in- } \\
\text { Kind Payment }\end{array}$}} \\
\hline & & & & & & & & \\
\hline & & & \multicolumn{2}{|c|}{$\begin{array}{c}1 / 2 \text { of Levied } \\
\text { Abiana }\end{array}$} & \multicolumn{2}{|c|}{$\begin{array}{c}1 / 4 \text { of Levied } \\
\text { Abiana }\end{array}$} & & \\
\hline & No. & $\%$ & No. & $\%$ & No. & $\overline{\%}$ & No. & $\%$ \\
\hline Head & 20 & 17.1 & 7 & 6.0 & 0 & 0 & 0 & 0 \\
\hline Middle & 20 & 17.1 & 17 & 14.5 & 0 & 0 & 7 & 6.0 \\
\hline Tail & 29 & 24.8 & 15 & 12.8 & 1 & 0.9 & 1 & 0.9 \\
\hline Total & 69 & 59 & 39 & 33.3 & 1 & 0.9 & 8 & 6.9 \\
\hline
\end{tabular}

Source: IIMI-Survey 1996.

Table 2

Abiana Estimated by Survey Data and by Khatoonies (in Rs) According to Location of Sample Farms

\begin{tabular}{lcccc}
\hline Location along & $\begin{array}{c}\text { Abiana }^{9} \\
\text { Estimated by } \\
\text { Survey Data }\end{array}$ & $\begin{array}{c}\text { Abiana }^{10} \\
\text { Estimated by } \\
\text { Khatoonies }\end{array}$ & Difference & $\%$ \\
\hline Head & 18,677 & 14,869 & 3,808 & 20.39 \\
Middle & 44,660 & 34,330 & 10,330 & 23.13 \\
Tail & 31,145 & 26,440 & 4,705 & 15.11 \\
Total & 94,481 & 75,639 & 18,842 & 19.94 \\
\hline Source: IIMI-Survey 1996 & & & &
\end{tabular}

Regarding perception about different abiana assessment procedures, Table 3 indicates that about 74 percent of farmers showed clear-cut resentment against the

present system of abiana assessment. About 43.6 percent of the farmers were in favour of the abiana assessment through farmers' own organisations. While the farmers in favour of "a flat rate"11 (per acre basis) were 29.6 percent. Only about 26.5 percent of the total sample farmers were in favour of the "existing abiana assessment system".

Table 4 shows, that in each of the three reaches of the H-4-R Distributary, the farmers reported the incidence of illegal payments. These payments were made to ensure water availability during the needy days as well as promises of some extra supplies, Chaudhry (1986) also reported this activity. About 41 percent of the respondents reported that during kharif 1995 and rabi 1995-96, they made payment

${ }^{9}$ Estimated abiana was calculated after multiplying the area taken from the questionnaire (in acres) under a crop with the rate per acre of that crop, charged by the government, in the same year.

${ }^{10}$ Abiana assessed and collected by the Revenue Department of ID.

${ }^{11}$ Flat Rate (per acre basis) means that the abiana levied per acre of crop sown will be the same without considering whether the crop sown is sugar cane or wheat, etc. 
Table 3

Perception of Sample Farmers about the Procedure to be Used for Abiana Assessment in Hakra 4-R Distributary

\begin{tabular}{lcccc}
\hline \multirow{2}{*}{$\begin{array}{l}\text { Location along } \\
\text { Distributary }\end{array}$} & Existing & $\begin{array}{c}\text { Abiana Assessment Procedure } \\
\text { Organisation }\end{array}$ & $\begin{array}{c}\text { Flat Rate } \\
\text { (Per Acre) }\end{array}$ & Any Other \\
\hline Head & 7 & 12 & 8 & 0 \\
& $(6.00 \%)$ & $(10.30 \%)$ & $(6.80 \%)$ & $(0.00 \%)$ \\
Middle & 11 & 17 & 17 & 0 \\
Tail & $(9.40 \%)$ & $(14.50 \%)$ & $(14.50 \%)$ & $(0.00 \%)$ \\
Total & 13 & 22 & 9 & 1 \\
& $(11.10 \%)$ & $(18.80 \%)$ & $(7.70 \%)$ & $(0.90 \%)$ \\
\end{tabular}

Source: IIMI-Survey 1996.

Table 4

Payment Made by Farmers for Ensuring Water Availability and Their Location Along the Hakra 4-R Distributary

\begin{tabular}{lcccccc}
\hline Location along & \multicolumn{3}{c}{ Yes } & & \multicolumn{3}{c}{ No } & & $\begin{array}{c}\text { Average Payment/ } \\
\text { Mohga in Rupees }\end{array}$ \\
\cline { 2 - 3 } Distributary & No. & $\%$ & & No. & $\%$ & \\
\hline Head & 13 & 11.11 & & 14 & 11.96 & 19,500 \\
Middle & 18 & 15.38 & & 27 & 23.07 & 19,800 \\
Tail & 17 & 14.52 & & 28 & 23.93 & 14,000 \\
Total & 48 & 41.01 & & 69 & 58.99 & \\
\hline
\end{tabular}

Source: IIMI-Survey 1996.

to the PID officials for ensuring the authorised/unauthorised water supply. This payment on the average ranges from Rs 14,000/Mogha (outlet) at the tail reach to Rs $19,800 /$ Mogha in the middle reach of the distributary. In each of the three reaches of the H-4-R Distributary, the farmers reported the incidence of such illegal payments.

\section{Operation and Maintenance Expenditures on Hakra 4-R Distributary}

Figure 2 shows the temporal pattern of operation and maintenance (expressed in real terms based on 1980-81 prices), incurred on the H-4-R Distributary. During 1975-76, 1984-85, and 1986-87, the rise in O\&M expenditures incurred on H-4-R Distributary was much higher compared with $\mathrm{O} \& \mathrm{M}$ expenditures in all other years. For further analysis the operation ${ }^{12}$ and maintenance expenditures were split into their sub-components, i.e. operational expenditures and maintenance expenditures.

\footnotetext{
${ }^{12}$ The breakup of O\&M expenses in different components is the same as mentioned by ACE (1990).
} 
Figure 3 shows the real operation and maintenance expenditures separately (in terms of 1980-81 prices). It is quite clear from Figure 3 that during all the past years, the major portion of the operation and maintenance expenditures were under the head of operational expenses. Since 1971-72, the expenditures on maintenance were minor and till to date, there are only few years (1984-85 to 1987-88 and 1994-95 to 199596) with high maintenance expenditures. The sharp booms in maintenance expenditures were due to closing mishaps and construction of foot bridge, etc. These were all one-time events and are not expected to be repeated (e.g. construction of a bridge). Poor maintenance in the remote past was taking its toll in terms of high maintenance expenditures after every six to eight years. Similar results are reported by Akhtar and Walter (1990).

Regarding the real abiana collection, it is concluded that the temporal abiana collection depicts a downward trend. Especially, in 1986-87, 1990-91 and 1992-93 the abiana collection was very low. (See Figure 4.)

Combining the estimates of abiana collected and operation and maintenance expenditures incurred on the H-4-R Distributary, Figure 5 shows that the abiana collected was always more than the O\&M expenditures incurred on the distributary, except for the year 1986-87. This shows that the farmers of H-4-R Distributary were contributing more in terms of abiana payments as compared with expenditures incurred on Hakra 4-R Distributary.

Table 5 shows that for the last five years, although the O\&M expenditures to abiana ratios were changing, but the last five years average expenses were only 62 percent of the abiana receipts collected.

Table 5

Abiana Collected vs. Operation and Maintenance Expenditures in the Last Five Years (Rs) in Hakra 4-R Distributary

\begin{tabular}{ccccc}
\hline Years & Abiana & O\&M & Difference & O\&M as \% of Abiana \\
1 & 2 & 3 & $4=(2-3)$ & $5=(3 / 2)$ \\
\hline $1991-92$ & $1,790,534$ & $1,075,900$ & 714,634 & 60.08 \\
$1992-93$ & $1,622,937$ & $1,087,517$ & 535,420 & 67.00 \\
$1993-94$ & $3,016,657$ & $1,315,488$ & $1,701,169$ & 43.60 \\
$1994-95$ & $2,641,268$ & $1,875,529$ & 765,739 & 71.00 \\
$1995-96$ & $2,837,515$ & $2,021,107$ & 816,408 & 71.22 \\
\hline
\end{tabular}

Source: PID office Bahawalnagar (1996).

Regarding the bottlenecks in better Operation and Maintenance, Box 1 provides the list of problems reported by the Irrigation Department Officials. First, there was the problem of funds (allocated at proper time) which were reported to be inadequate for the proper operation and maintenance. Moreover, the PID officials claimed that even from these allocated funds for H-4-R Distributary, a part was diverted to other projects at some other distributary. 


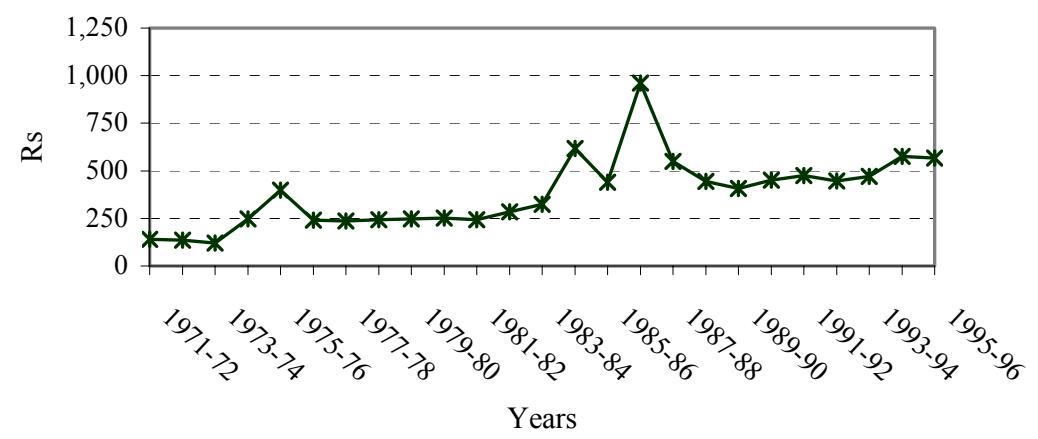

Fig. 2. Total O\&M Expenses incurred for Hakra 4-R Distributary during the Years 1971-72 to 1995-96 (Rs).

Operating vs Maintenance Expenses of Hakra 4-R Distributary (Base Year 1980-81)

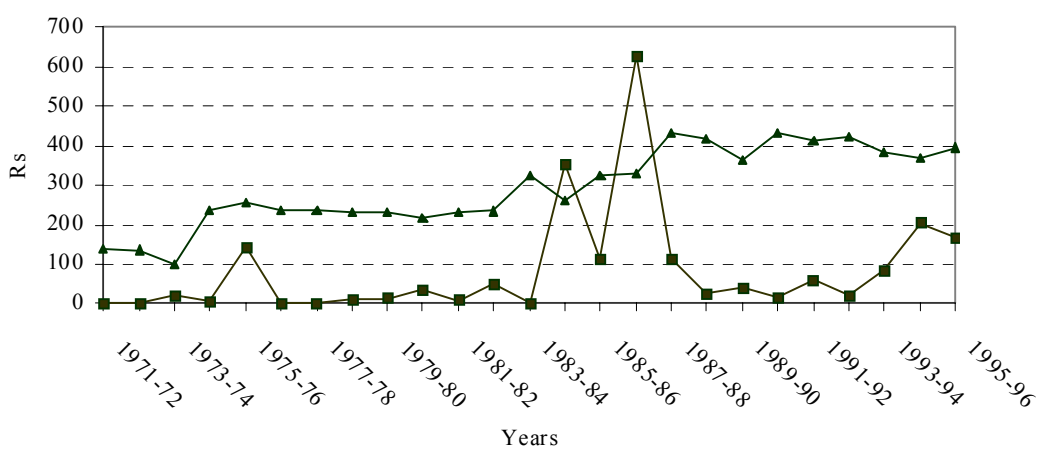

$\multimap-$ Maintenance $\longleftarrow$ Operation

Source: PID office, Bahawalnagar.

Fig. 3. Operational vs Maintenance Expenses Incurred on Hakra 4-R Distributary from the Years 1971-72 to 1995-96 (Rs). 
Abiana Collection of Hakra 4-R Distributary (Base Year 1980-81)

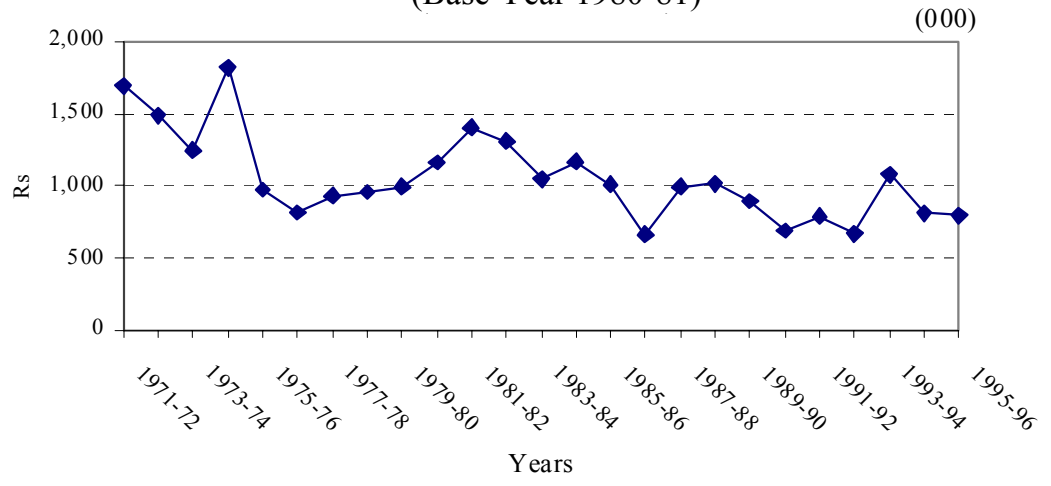

Fig. 4. The Abiana Receipts of Hakra 4-R Distributary from the Years 1971-72 to 1995-96 (Rs).

O \& M Expenses vs Abiana Collected of Hakra 4-R Distributary (Base Year 1980-81)

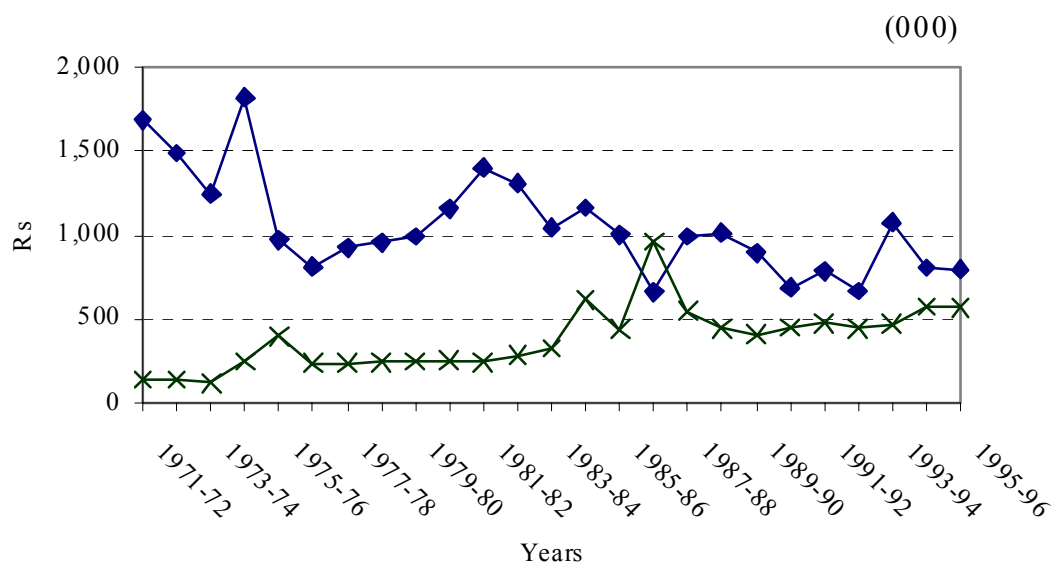

$\sim$ Abiana $\rightarrow$ O\&M

Fig. 5. Abiana Receipts and O\&M Expenses of Hakra 4-R Distributary from the Year 1975-76 to 1995-96 (Rs). 
Second, the PID officials reported the need more for staff than available at present. One Baildar ${ }^{13}$ was appointed for every fifteen RD's. ${ }^{14}$ Normally he was unable to maintain that part of the distributary properly. PID officials reported that after a tender invitation by the Irrigation Department, the contractors usually colluded and only one bid was filed. In this way, they eliminated competition among them. As a result, there were very minute differences between the estimates made by Government officials and the value of the bid filed by the contractors. Regarding the availability of machinery and equipment, the irrigation officials reported that there was no machinery available with PID for accomplishing the required maintenance work. The PID has to hire tractors and other equipment when needed.

Box 2 reports the problems faced by the contractors. The contractors reported that the funds allocated by PID for the required maintenance work were inadequate. Moreover, the release of funds was not on time and even these instalments were not adequate. The contracts were granted, but the funds were released after deducting a commission. Regarding the estimates, contractors claimed that the estimates advertised by the PID usually overestimated the O\&M expenditures. Similar findings were reported by Rao and Bottral (1984).

Regarding the approval of the tenders by PID officials, contractors responded that they had to pay at least 15-20 percent (of the tender money) as unauthorised payment for approval of the tenders. The extent of unauthorised payment varied according to the value of the tender.

\section{LIST OF BOTTLENECKS REPORTED BY PID OFFICIALS TO IMPROVE O\&M ON HAKRA-4-R}

\section{Funds}

Inadequate funds.

Diversion of funds to other projects.

\section{Staff}

Small size staff.

Unavailability of unskilled labour when needed.

\section{Tender Work}

Illegal collusion among contractors for getting the tenders at highest rates.

Machinery and Equipment

Unavailability of necessary machinery and equipment.

Source: IIMI-Survey 1996.

\section{Box 1. List of Bottlenecks Reported by PID Officials to Improve O\&M.}

\footnotetext{
${ }^{13} \mathrm{~A}$ lower cadre ID official who looks after the distributary/canal.

${ }^{14} \mathrm{RD}=$ Reduced Distance where $1 \mathrm{RD}$ is equal to 1000 feet.
} 


\section{LIST OF BOTTLENECKS REPORTED BY CONTRACTORS FOR O\&M WORK}

Funds

Inadequate funds.

Delays in release of funds.

Release of funds in inadequate amounts.

\section{Cost Estimation}

Unrealistic estimates (over estimation of costs by PID).

\section{Tender Work}

Delay in approval of Work tenders by PID officials.

Demand for high commission by PID officials.

Source: IIMI-Survey 1996.

Box 2. List of Bottlenecks Reported by Contractors for O\&M Work in Hakra 4-R.

\section{CONCLUSIONS AND RECOMMENDATIONS}

The results of the analysis of abiana collected and O\&M expenses incurred show that the abiana collection was almost always in excess to the operational and maintenance expenses incurred on H-4-R Distributary.

From the analysis, it is clear that the real cause of low abiana collection is abiana under-assessment. So abiana assessment procedure should be improved. The representatives of the already existing water user organisations at the watercourse level and relevant Patwari may be involved in abiana assessment.

It is recommended that before the tender invitation, the farmer organisations may be involved in the estimation of the maintenance work. Moreover representatives of farmer organisations must be present at the time of tender opening to ensure that the lowest tender is approved.

It is also suggested that the farmer organisations should also keep an eye on maintenance works completed by the contractors under the supervision of PID. The monitoring and evaluation may be undertaken by the representative committee of the farmer's organisations (whether the prescribed maintenance works are actually taking place or not). The treasury should not release any instalment to contractors without prior certification and verification on the measurement book, which indicates that the work was actually completed and was up to the standard requirements.

The total budget allocations for the operation and maintenance activities of canals may be increased according to the requirement. It is proposed that the budget allocations for any unit of irrigation system must also consider the receipts of abiana collected from that unit. 
It is anticipated that if the activities of abiana assessment, collection, and incurring of O\&M expenses are with farmer organisation, it can improve since both will become interdependent. High abiana recovery will also lead to rise in ability of the farmer organisation to spend more to improve O\&M.

It is also suggested that to compare the situation countrywide similar studies should also be conducted in the command areas of other distributaries.

\section{REFERENCES}

Akhtar, M., and F. Walter (1990) Pakistan Agriculture: A Description of Pakistan's Agricultural Economy. Directorate of Agricultural Policy and Chemonics International Consulting Division for the Economic Analysis Network, Islamabad.

Associated Consulting Engineers (ACE) (1990) Nation-wide Study for Improving Procedures for the Assessment and Collection of Water Charges and Drainage Cess. Vol. I of III, Lahore, Pakistan.

Carruthers, I. (1981) Neglect of O\&M in Irrigation: The Need for New Sources and Forms of Support. Water Supply and Management 5: 53-65. Great Britain: Pergamon Press Ltd.

Chaudhry, M. A. (1986) Irrigation Water Charges and Recurrent Cost Recovery. Paper Presented at FAO, AID Expert Consultation on Irrigation Water Charges, Rome, 22-26 September. 31 p.

Chaudhry, M. A. (1989) Benefits to O\&M Expenditure in the Canal System in Punjab. Pakistan Economic Analysis Network Project, Chemonics International Consulting Division, Islamabad.

Haq, A. (1995) Improving Irrigation System Performance: Major Issues and Options. Pakistan Journal of Water Resources 1:1 54-56.

Rao, P. K., and A. Bottral (1984) Introduction to Discussion on Water Rates. Overseas Development Institute, 10-11 Percy Street, London. (ODI Network Paper 10f.)

Small, L. E. (1989) User Charges in Irrigation: Potentials and Limitations. Irrigation and Drainage Systems 3: 125-142. Kluwer Academic Publishers, Netherlands.

World Bank (1988) Second Irrigation Rehabilitation Project. World Bank, Islamabad. (Staff Appraisal Report No. 6991-PAK.)

World Bank (1994) Pakistan-A Strategy for Sustainable Agricultural Growth. (Report No. 13092-PAK.) 